\title{
Cytotoxicity and stress gene microarray analysis in cadmium-exposed CRL-1439 normal rat liver cells
}

\author{
VEERA L.D. BADISA ${ }^{1,2}$, LEKAN M. LATINWO ${ }^{1}$, CAROLINE O. ODEWUMI ${ }^{1}$, CHRISTOPHER O. IKEDIOBI ${ }^{2}$, \\ RAMESH B. BADISA ${ }^{3}$, ALEXIS BROOKS-WALTER ${ }^{1,5}$, AYUK-TAKEM T. LAMBERT ${ }^{2}$ and JUDE NWOGA ${ }^{4}$
}

\author{
Departments of ${ }^{1}$ Biology, ${ }^{2}$ Chemistry, College of Arts and Sciences; ${ }^{3}$ College of Pharmacy and \\ Pharmaceutical Sciences, Florida A\&M University, Tallahassee, FL 32307; ${ }^{4}$ Institute of Physical \\ Therapy, University of St. Augustine, Department of Physiology, St. Augustine, FL 32084, USA
}

Received February 21,2008; Accepted April 18, 2008

DOI: 10.3892/ijmm_00000011

\begin{abstract}
Cadmium is a biologically non-essential divalent hazardous metal. Previous studies demonstrated that cadmium toxic effect was caused by reactive oxygen species. Since gene expression is influenced by the presence of these reactive oxygen species, the association between metal intoxication and gene expression has recently become a major focus of research. We examined the effect of cadmium chloride on cell viability at 4,8 and $24 \mathrm{~h}$. Our results indicate that cadmium chloride did not alter cell viability at 4 or $8 \mathrm{~h}$, but decreased the viability in a dose-dependent manner ( $p>0.01$ ) at $24 \mathrm{~h}$. Using DNA microarray, we studied the profile of stress gene expression in rat primary hepatocytes treated with cadmium for different time periods using a $100 \mu \mathrm{M}$ cadmium chloride concentration. Microarray analysis indicated that cadmium treatment caused different patterns of gene expression profiles at each time point of incubation. Of the 207 stress genes on the microarray, only 32 genes were regulated. Since microarrays were hybridized by radioactive cDNA which was less sensitive than fluorescent-labeled cDNA, an experimental/control ratio $>1.3$ or $<0.7$ (30\% increase or decrease) was taken as significant up- or down-regulation. Exposure of cells to cadmium for $4 \mathrm{~h}$ resulted in the expression of three up-regulated genes and six down-regulated genes. Longer exposure to cadmium for $8 \mathrm{~h}$ resulted in an increase in up-regulated genes to six and down-regulated genes to 14 . After $24 \mathrm{~h}$ of cadmium exposure, 15 genes were down-regulated and six genes were up-regulated. Our findings suggest that the cells maintained complete viability up to $8 \mathrm{~h}$ with cadmium due to expression of various heat shock proteins and stress response proteins like heme oxygenase. Longer
\end{abstract}

Correspondence to: Dr L.M. Latinwo, Department of Biology, College of Arts and Sciences, Florida A\&M University, Tallahassee, FL 32307, USA

E-mail: lekan.latinwo@famu.edu

Present address: ${ }^{5}$ Bethune Cookman University, School of Science Engineering and Mathematics, Daytona Beach, FL 321143099, USA

Key words: cadmium chloride, DNA microarray, CRL-1439 rat liver cells, stress, viability exposure periods, due to the down-regulation of the basic cell function proteins and cell-cycle regulating proteins, led to toxicity in cells and eventually to cell death.

\section{Introduction}

Cadmium is the seventh hazardous heavy metal listed by the Agency of Toxic Substances and Disease Registry (1). It is also classified by IARC as a group I carcinogen for humans (2). It is an immunotoxicant causing damage to both humoral and cell-mediated immunity $(3,4)$. Cadmium is present in cigarette smoke and in certain environmental conditions. It enters the human food chain through crops grown in soil treated with cadmium contaminated phosphate fertilizers, and sewage sludge $(5,6)$. It is used in electroplating and the manufacture of batteries, plastics, paints, alloys and fertilizers. It is also generated as a by-product in the mining of lead, copper and zinc. Cadmium accumulates in many organs such as kidney, liver, lung, testis, brain and bone (7) and causes cancer in those organs $(7,8)$.

DNA microarrays are the most powerful and reliable tools for monitoring the expression of thousands of genes simultaneously in a shorter time period (9-11). DNA arrays are used extensively in drug discovery and development (12), in identifying changes in gene expression associated with various disease processes, and screening populations for allelic variants (13-16). There is increasing interest in the use of arrays in toxicology to study the expression profiles of genes after exposure to a toxicant (17-19). Recently, microarray analysis studies with cadmium were reported in plants (20-23), mice $(24,25)$, rats (26), and human cells or cell lines (27-31). Earlier we reported the response of antioxidant enzymes and redox metabolites to cadmium-induced oxidative stress in CRL-1439 normal rat liver cells (32). We also reported the effect of cadmium-induced oxidative stress on antioxidative enzymes in mitochondria and cytoplasm of CRL-1439 normal rat liver cells (33). In this study, we examined the effect of cadmium chloride on cell viability of CRL-1439 normal rat liver cells at 4, 8 and $24 \mathrm{~h}$ at different concentrations $(0-175 \mu \mathrm{M})$. We also reporting the rat stress microarray expression profiles of CRL-1439 normal rat liver cells exposed to $100 \mu \mathrm{M}$ cadmium chloride for 4,8 and $24 \mathrm{~h}$, respectively. 


\section{Materials and methods}

Chemicals. Inorganic $\mathrm{CdCl}_{2}$, $\mathrm{SDS}$, sodium chloride, sodium citrate and salmon sperm DNA were purchased from SigmaAldrich (St. Louis, MO, USA). The Atlas Mouse cDNA microarrays (catalog no. 7735-1 Rat Stress Array, containing 207 genes), cDNA preparation kit, hybridization solution, microspin columns and solutions were obtained from Clontech (Palo Alto, CA, USA). TRIzol Reagent was obtained from Life Technologies Inc. (Gathersburg, MD, USA), BioMax Kodak X-ray film was from Fisher Scientific Co. (Suwanne, GA, USA) and $\left[\alpha^{-32} \mathrm{P}\right]$-dATP was from Amersham (Piscataway, NJ, USA). $\mathrm{CdCl}_{2}$ stocks and working stocks were prepared in deionized water.

Maintenance of cell line. Rat normal liver epithelial cell line (CRL-1439) was purchased from the American Type Culture Collection (ATCC, Rockville, MD, USA) at the passage number 17 stage. The frozen cells were thawed rapidly within $1 \mathrm{~min}$ at $37^{\circ} \mathrm{C}$, transferred into $\mathrm{T}-75$ culture flasks and maintained according to ATCC instructions. The cells were grown as monolayer cultures in $\mathrm{F} 12 \mathrm{~K}$ medium containing $100 \mathrm{U} \mathrm{ml}^{-1}$ of penicillin, $100 \mu \mathrm{g} \mathrm{ml}^{-1}$ of streptomycin, $2 \mathrm{mM}$ glutamine and $10 \%$ fetal bovine serum (FBS) in T-75 flasks at $37^{\circ} \mathrm{C}$ in a $5 \% \mathrm{CO}_{2}$ incubator. When the cells were $\sim 85 \%$ confluent, they were sub-cultured by treating with trypsin $(0.25 \%)$. Cell counts and cell viability were assessed by using $0.4 \%$ trypan blue stain on a hemocytometer under light microscope. Dyestained cells (blue) were counted as dead cells, while dyeexcluded cells were counted as viable cells. Cells were diluted in the media and then seeded in culture plates for the experiments.

Treatment of cells with cadmium. The cytotoxic effect of cadmium was studied in polystyrene, flat-bottom 24-well culture plates. For this purpose, cells were plated at an initial density of $10 \times 10^{4}$ cells in each well in a final volume of $990 \mu 1$ complete medium and allowed to stabilize overnight in a $\mathrm{CO}_{2}$ incubator at $37^{\circ} \mathrm{C}$. Next day, the cells were treated with concentrations of $\mathrm{CdCl}_{2}(25,50,75,100,125,150$ and $175 \mu \mathrm{M})$ in triplicate wells. Sterile distilled water or medium was added to the control wells. The test and control wells were always in the same 24 -well plates. The plates were covered and incubated for 4,8 or $24 \mathrm{~h}$ continuously. All studies were repeated independently at least twice $(n=6)$.

Evaluation of cytotoxicity of cadmium. At the end of each incubation period, the cytotoxicity of cadmium was evaluated by dye-uptake assay using crystal violet (34). Briefly, at the end of the incubation, $400 \mu \mathrm{l}$ of $0.25 \%$ glutaraldehyde in $\mathrm{H}_{2} \mathrm{O}$ was added to each well and incubated for $30 \mathrm{~min}$ at room temperature to fix the cells. The plates were washed under tap water and dried under airflow inside the laminar hood for 5-10 min. Four hundred microliters of $0.1 \%$ crystal violet in $\mathrm{H}_{2} \mathrm{O}$ were added to each well, incubated for $15 \mathrm{~min}$, washed with tap water, and dried at room temperature. Later, $400 \mu 1$ of $0.05 \mathrm{M}$ sodium phosphate solution in $50 \%$ ethyl alcohol was added to each well to solubilize the dye, and the plates were read at $540 \mathrm{~nm}$ in a plate reader. The average absorbance values of controls were taken as $100 \%$ cell viability. From the treated and control absorbance values, the percent cells killed were determined by the following equation: [1 - (T/C)] $\mathrm{x} 100$, where $\mathrm{T}$ is average absorbance values of treated cells, and $\mathrm{C}$ is average absorbance values of control cells.

$E D_{50}$ determination. Since the cell viability in the present study was not affected significantly at 4- and 8-h exposure periods with various concentrations of cadmium, the data obtained at $24 \mathrm{~h}$ of treatment was utilized for plotting graphs between the concentration of cadmium on the x-axis and the percent cell population (both viability and dead) on the yaxis. The graphs were plotted using the GraphPad Prism Software, version 3.00 (San Diego, CA, USA). The effective dose of cadmium that killed $50 \%$ cells $\left(\mathrm{ED}_{50}\right)$ was calculated from the graph as the point where both curves intersected (35).

Statistical analysis. The viability results were presented as mean $\pm \operatorname{SD}(n=6)$. The data were analyzed for significance by one-way ANOVA, and then compared by Dunnett's multiple comparison tests, using GraphPad Prism Software, version 3.00 . The test value $p<0.01$ was considered a highly significant comparison to the respective untreated control.

Treatment with cadmium, isolation of total RNA and cDNA microarray analysis. Approximately $1.3 \times 10^{6}$ cells in T-25 flasks were used for total RNA extraction. The cells in triplicate flasks were treated with 0 or $100 \mu \mathrm{M} \mathrm{CdCl}_{2}$ and incubated for 4,8 or $24 \mathrm{~h}$ at $37^{\circ} \mathrm{C}$ in a $5 \% \mathrm{CO}_{2}$ incubator. After incubation periods, the cells in the flasks were trypsinized, pooled together and pelleted by centrifugation at $2,000 \mathrm{rpm}$ for $10 \mathrm{~min}$. The total RNA from the pooled cells was isolated by using TRIzol according to the manufacturer's instructions. The stable cDNAs were prepared and labeled from the total RNA by BD BioSciences cDNA kit using $\left[\alpha-{ }^{32} \mathrm{P}\right]-$ dATP. The Clontech Atlas microarrays containing 207 rat stress genes were probed according to the manufacturer's instructions. Briefly, $5 \mu \mathrm{g}$ of total RNA was converted to ${ }^{32} \mathrm{P}-$ labeled cDNA probes using MuLV reverse transcriptase and $\left[\alpha^{-32} \mathrm{P}\right]-\mathrm{dATP}$ with the Clontech Atlas cDNA synthesis primers. The $\left.{ }^{[32} \mathrm{P}\right]$-labeled cDNA probes were purified with NucleoSpin Columns (Clontech) and denatured at $100^{\circ} \mathrm{C}$ for 5 min before adding into a hybridization bag. The microarray membranes were prehybridized with Expresshyb hybridization solution for $2 \mathrm{~h}$ at $68^{\circ} \mathrm{C}$ followed by overnight hybridization at $68^{\circ} \mathrm{C}$ with the $\left[{ }^{32} \mathrm{P}\right]$-labeled cDNA probes. The membranes were washed twice with $2 \mathrm{X} \mathrm{SSC}+1 \%$ SDS at $68^{\circ} \mathrm{C}$ for $30 \mathrm{~min}$ each, and once with $0.5 \mathrm{X} \mathrm{SSC}+0.5 \%$ SDS at room temperature for $30 \mathrm{~min}$. The membranes were exposed to $\mathrm{X}$-ray film at $-70^{\circ} \mathrm{C}$ for seven days and developed in an automatic X-ray developer. The films were scanned with the scanner, and density of the dots was measured for up-regulated or down-regulated genes by using AtlasImage 2.7 software (BD Biosciences).

\section{Results}

Cell viability. The toxic nature of cadmium at different concentrations was evaluated against various cell cultures in earlier studies $(36,37)$. However, the effect of cadmium on 
cell viability of rat normal hepatocytes at different concentrations for different time periods had not been previously tested. Therefore, we studied the cadmium dose response on cell viability after 4,8 or $24 \mathrm{~h}$ in this cell line. For this purpose, a total of seven different concentrations of cadmium, 25, 50, $75,100,125,150$ and $175 \mu \mathrm{M}$, were tested and cell viability was assessed by crystal violet dye staining method. This method is simple and reproducible as reported earlier $(34,38)$. As per this method, the intensity of violet color is proportional to the number of live cells. Notably, cell viability was not affected at any concentration of cadmium up to $8 \mathrm{~h}$ of incubation (Fig. 1). However, after $24 \mathrm{~h}$ of exposure, cadmium displayed a gradual increase in toxicity from $25 \mu \mathrm{M}$ onwards in a dose-dependent manner ( $\mathrm{p}<0.01$, Fig. 1). The $\mathrm{ED}_{50}$ value at this time point was determined to be $125 \mu \mathrm{M}$ (Fig 1b). Since our objective was to study the effect of cadmium on gene expression where it shows medium toxicity, we selected the $100 \mu \mathrm{M}$ cadmium concentration for microarray analysis at different time points.

Microarray analysis. To study the expression profiles of cadmium-induced stress genes, rat normal hepatocytes were exposed to a fixed concentration of $100 \mu \mathrm{M}$ cadmium for 4,8 or $24 \mathrm{~h}$. This concentration was selected based upon results of our previous (32) and present studies. While the total number of genes regulated in this study is summarized in Table I, the up- or down-regulated genes are shown separately in Tables II-VII. It is notable that the number of downregulated genes was greater than the up-regulated genes at all time points upon exposure to cadmium. Since most of the down-regulated genes account for such basic cell functions as transcription, translation, and cell-cycle, their down-regulation may explain the toxic effect of cadmium on these cells.

\section{Gene regulation with cadmium exposure}

Up-regulated genes. Out of 207 stress genes on the array, a total of nine genes were up-regulated during a 24-h exposure with cadmium at $100 \mu \mathrm{M}$ concentration. After $4 \mathrm{~h}$, only three genes were up-regulated (Table II). These were heme oxygenase-1 (HO-1), heat shock $27 \mathrm{KD}$ protein 1 , and heat shock 70-1 (hsp 70-1). After an 8-h exposure, in addition to the above three genes, three new genes were up-regulated (Table III). These were heat shock $10 \mathrm{KD}$ protein 1, diaphorase (NADH/NADPH), and stress-induced phosphoprotein 1 . After $24 \mathrm{~h}$, in addition to the three genes up-regulated after a 4-h exposure, three new genes were up-regulated (Table IV). These were tumor rejection antigen (gp96)1, DNA J-like protein, and heat shock $70 \mathrm{KD}$ protein 5 .

Down-regulated genes. Out of 207 stress genes on the array, a total of 23 genes were down-regulated during a 24-h exposure with cadmium at $100 \mu \mathrm{M}$ concentration. After $4 \mathrm{~h}$ of exposure, six genes were down-regulated (Table V). These were glutathione-S-transferase mu type 2 (Yb2), nucleoside diphosphate kinase, inhibitor of DNA binding 3, cyclin D3, glucose regulated protein $58 \mathrm{KD}$, and microsomal glutathione $\mathrm{S}$-transferase. After $8 \mathrm{~h}$ of exposure, in addition to three of the above-mentioned genes (glutathione-S-transferase mu type 2 (Yb2), cyclin D3 and inhibitor of DNA binding 3), 11 new genes (total 14 genes) were down-regulated (Table VI). These were vimentin, Finkel-Biskis-Reilly murine sarcoma
A

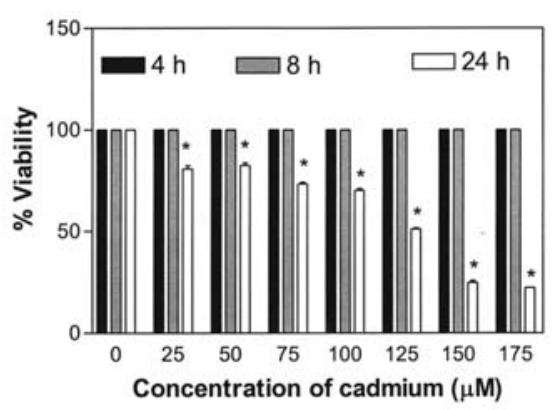

B

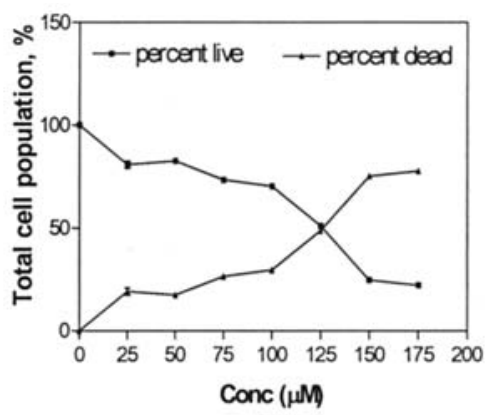

Figure 1. (a) Effect of cadmium on rat normal liver cell viability after 4, 8 or $24 \mathrm{~h}\left(\mathrm{n}=6,{ }^{*} \mathrm{p}<0.01\right.$, compared to control by Dunnett's multiple comparison test). (b) $\mathrm{ED}_{50}$ of cadmium on rat normal liver cells at $24 \mathrm{~h}$.

Table I. The number of genes regulated on the array at each time point, after incubation with cadmium.

\begin{tabular}{cccc}
\hline $\begin{array}{l}\text { Incubation } \\
\text { period }\end{array}$ & $\begin{array}{c}\text { No. of genes } \\
\text { up-regulated }\end{array}$ & $\begin{array}{c}\text { No. of genes } \\
\text { down-regulated }\end{array}$ & $\begin{array}{c}\text { Total genes } \\
\text { regulated }\end{array}$ \\
\hline $4 \mathrm{~h}$ & 3 & 6 & 9 \\
$8 \mathrm{~h}$ & 6 & 14 & 20 \\
$24 \mathrm{~h}$ & 6 & 15 & 21 \\
\hline
\end{tabular}

virus, inhibitors of DNA binding 1 and 2, glutathione peroxidase 1 , high mobility group box 2 , cyclin-dependent kinase inhibitor 1 B (P27, Kip 1), heterogeneous nuclear ribonucleoprotein $\mathrm{K}$, cell cycle protein p55CDC, cyclin D1, and proliferating cell nuclear antigen.

After $24 \mathrm{~h}$ of cadmium treatment, in addition to three genes from the 4-h exposure [i.e. glutathione-S-transferase mu type 2 (Yb2), inhibitor of DNA binding 3, cyclin D3] and five genes from the 8 -h exposure [i.e. glutathione peroxidase 1 , high mobility group box 2, cyclin-dependent kinase inhibitor 1B (P27, Kip 1), inhibitor of DNA binding 1, and heterogeneous nuclear ribonucleoprotein $\mathrm{K}$ ] seven new genes (total 15 genes) were down-regulated (Table VII). These were mitogen activated protein kinase $1, \mathrm{~T}$-complex protein 1 eta subunit, structure specific recognition protein 1, amphiphysin, cyclin-dependent kinase 4, diaphorase, and prothymosin $\alpha$.

\section{Discussion}

Cadmium is a non-essential metal which is retained in the liver with a half-life exceeding 20 years in humans and thus shown to have a marked impact on health. As the liver is one of the major organs that are susceptible to cadmium toxicity, 
Table II. Up-regulated genes in rat normal liver cells at $4 \mathrm{~h}$ of $100 \mu \mathrm{M}$ cadmium exposure.

\begin{tabular}{lcccc}
\hline $\begin{array}{l}\text { ID no. } \\
\text { on array }\end{array}$ & Gene name & $\begin{array}{c}\text { Average intensity in } \\
\text { control array (2 dots) }\end{array}$ & $\begin{array}{c}\text { Average intensity in } \\
\text { experimental array }\end{array}$ & $\begin{array}{c}\text { Ratio } \\
\text { (expt/control) }\end{array}$ \\
\hline E7 & Heme oxygenase & 33938 & 55630 & 1.6 \\
J5 & Heat shock 27 KD protein 1 & 33852 & 55612 & 1.6 \\
M5 & Heat shock protein 70-1 & 35768 & 56192 & 1.6 \\
\hline
\end{tabular}

Table III. Up-regulated genes in rat normal liver cells at $8 \mathrm{~h}$ of $100 \mu \mathrm{M}$ cadmium exposure.

\begin{tabular}{lcccc}
\hline $\begin{array}{l}\text { ID no. } \\
\text { on array }\end{array}$ & Gene name & $\begin{array}{c}\text { Average intensity in } \\
\text { control array }\end{array}$ & $\begin{array}{c}\text { Average intensity in } \\
\text { experimental array }\end{array}$ & $\begin{array}{c}\text { Ratio } \\
\text { (expt/control) }\end{array}$ \\
\hline D6 & Stress-induced phosphoprotein 1 & 40992 & 55252 & 1.35 \\
E6 & Heat shock 10 KD protein 1 & 35394 & 54624 & 1.54 \\
E7 & Heme oxygenase & 29186 & 56384 & 1.90 \\
E8 & Diaphorase (NADH/NADPH) & 32834 & 44272 & 1.35 \\
J5 & Heat shock 27 KD protein 1 & 33104 & 55924 & 1.69 \\
M5 & Heat shock protein 70-1 & 32587 & 55724 & 1.71 \\
\hline
\end{tabular}

Table IV. Up-regulated genes in rat normal liver cells at $24 \mathrm{~h}$ of $100 \mu \mathrm{M}$ cadmium exposure.

\begin{tabular}{lcccc}
\hline $\begin{array}{l}\text { I.D. no. } \\
\text { on array }\end{array}$ & Gene name & $\begin{array}{c}\text { Average intensity in } \\
\text { control array }\end{array}$ & $\begin{array}{c}\text { Average intensity in } \\
\text { experimental array }\end{array}$ & $\begin{array}{c}\text { Ratio } \\
\text { (expt/control) }\end{array}$ \\
\hline E7 & Heme oxygenase & 27764 & 56832 & 2.1 \\
I7 & Tumor rejection antigen (gp96)1 & 40200 & 56852 & 1.41 \\
J5 & Heat shock 27 KD protein 1 & 31248 & 56860 & 1.82 \\
K6 & DNA J-like protein & 30416 & 50568 & 1.66 \\
M5 & Heat shock protein 70-1 & 30508 & 56344 & 1.85 \\
M8 & Heat shock 70 KD protein 5 & 28672 & 54992 & 1.92 \\
\hline
\end{tabular}

in the present study, we used normal rat hepatocytes as a model system to evaluate cell viability and the response of various stress-related genes by microarray technique.

The data obtained from this study indicate that cadmium is toxic to normal rat liver cells with an $\mathrm{ED}_{50}$ of $125 \mu \mathrm{M}$ after $24 \mathrm{~h}$ of exposure. This value seems to be higher than the earlier reported value on a human hepatoma (HepG2) cell line, where the $\mathrm{ED}_{50}$ ranged between 18-26 $\mu \mathrm{M}(39)$ at $24 \mathrm{~h}$ of incubation. One of the reasons for this significant variation in $\mathrm{ED}_{50}$ values may be due to differences in species (rat or human) and the nature of cell cultures (normal or cancerous) employed for cytotoxic studies. The seeding density of cells in culture plates also influences the cytotoxic results (40), but in this case it is unlikely that this is the cause of $\mathrm{ED}_{50}$ variation as the number of cells plated in our viability studies was almost the same $\left(10,500\right.$ cells $\left./ \mathrm{cm}^{2}\right)$ as that of the earlier study $\left(10,000\right.$ cells $\left./ \mathrm{cm}^{2}\right)$ with a human hepatoma cell line (39). To some extent the variation in $\mathrm{ED}_{50}$ values may also depend upon assay method employed for cytotoxic assessment. From analysis of other studies, it appears that methodology may be one of the possible reasons for $\mathrm{ED}_{50}$ variation in our study.
For example, we employed a crystal violet dye binding viability method as against the MTT method employed by Urani et al (39). Indeed, the significance of assay methods with regard to different $\mathrm{ED}_{50}$ values was also clearly demonstrated in the same study. The authors evaluated the cytotoxic effect of cadmium on HepG2 cells after $24 \mathrm{~h}$, with two different methods MTT and protein concentration measurement, and the $\mathrm{IC}_{50}$ values were determined to be 25.5 and $18.38 \mu \mathrm{M}$, respectively (39). Therefore, the significant difference in these values clearly proves that $\mathrm{ED}_{50}$, or $\mathrm{IC}_{50}$ or $\mathrm{LC}_{50}$ values, apart from other factors, also depend significantly on the method of assessment of cell viability. For the same reasons discussed above, the $\mathrm{ED}_{50}$ value $(125 \mu \mathrm{M})$ in our study also significantly differed from that of the previous study (39). The $100 \mu \mathrm{M}$ cadmium concentration used in our study was taken as an optimal dose for microarray analysis depending on our previous (32) and present viability assay results.

In addition to dose-response toxicity study, we also investigated time course in order to pinpoint the onset of cadmium toxicity. Interestingly 4- or 8-h exposures did not alter cell viability (Fig. 1), which may indicate the self-protection of 
Table V. Down-regulated genes in rat normal liver cells at $4 \mathrm{~h}$ of $100 \mu \mathrm{M}$ cadmium exposure.

\begin{tabular}{lcccc}
\hline $\begin{array}{l}\text { ID no. } \\
\text { on array }\end{array}$ & Gene name & $\begin{array}{c}\text { Average intensity in } \\
\text { control array }\end{array}$ & $\begin{array}{c}\text { Average intensity in } \\
\text { experimental array }\end{array}$ & $\begin{array}{c}\text { Ratio } \\
\text { (expt/control) }\end{array}$ \\
\hline C17 & Microsomal glutathione S-transferase & 44336 & 29618 & 0.67 \\
E17 & Glutathione-S-transferase mu type 2 (Yb2) & 44220 & 29290 & 0.66 \\
F4 & Nucleoside diphosphate kinase & 45054 & 30912 & 0.69 \\
H8 & Glucose regulated protein 58 KD & 48698 & 30650 & 0.63 \\
J10 & Inhibitor of DNA binding 3 & 55896 & 34576 & 0.62 \\
M9 & Cyclin D3 & 42090 & 27778 & 0.66 \\
\hline
\end{tabular}

Table VI. Down-regulated genes in rat normal liver cells at $8 \mathrm{~h}$ of $100 \mu \mathrm{M}$ cadmium exposure.

\begin{tabular}{|c|c|c|c|c|}
\hline $\begin{array}{l}\text { ID no. } \\
\text { on array }\end{array}$ & Gene name & $\begin{array}{l}\text { Average intensity in } \\
\text { control array }\end{array}$ & $\begin{array}{l}\text { Average intensity in } \\
\text { experimental array }\end{array}$ & $\begin{array}{c}\text { Ratio } \\
\text { (expt/control) }\end{array}$ \\
\hline $\mathrm{C} 18$ & Glutathione peroxidase 1 & 51552 & 35072 & 0.68 \\
\hline D15 & High mobility group box 2 & 49476 & 25576 & 0.52 \\
\hline E10 & Cyclin-dependent kinase inhibitor 1B (P27, Kip1) & 35772 & 24384 & 0.68 \\
\hline E17 & Glutathione-S-transferase mu type 2 (Yb2) & 55258 & 32050 & 0.58 \\
\hline F10 & Cell cycle protein p55CDC & 44288 & 24680 & 0.56 \\
\hline H10 & Inhibitor of DNA binding 1 & 56388 & 24640 & 0.44 \\
\hline I10 & Inhibitor of DNA binding 2 & 47156 & 23808 & 0.50 \\
\hline $\mathrm{J} 10$ & Inhibitor of DNA binding 3 & 55710 & 29258 & 0.53 \\
\hline K9 & Cyclin D1 & 38968 & 24264 & 0.62 \\
\hline L11 & Heterogeneous nuclear ribonucleo protein $\mathrm{K}$ & 50680 & 24176 & 0.48 \\
\hline M6 & Vimentin & 55704 & 34052 & 0.61 \\
\hline M9 & Cyclin D3 & 54258 & 35268 & 0.65 \\
\hline M12 & Proliferating cell nuclear antigen & 42948 & 24520 & 0.57 \\
\hline N6 & Finkel-Biskis-Reilly murine sarcoma virus & 39672 & 24748 & 0.62 \\
\hline
\end{tabular}

Table VII. Down-regulated genes in rat normal liver cells $24 \mathrm{~h}$ of $100 \mu \mathrm{M}$ cadmium exposure.

\begin{tabular}{|c|c|c|c|c|}
\hline $\begin{array}{l}\text { ID no. } \\
\text { on array }\end{array}$ & Gene name & $\begin{array}{l}\text { Average intensity in } \\
\text { control array }\end{array}$ & $\begin{array}{l}\text { Average intensity in } \\
\text { experimental array }\end{array}$ & $\begin{array}{c}\text { Ratio } \\
\text { (expt/control) }\end{array}$ \\
\hline $\mathrm{C} 3$ & Mitogen activated protein kinase 3 & 39364 & 25660 & 0.65 \\
\hline $\mathrm{C} 7$ & T-complex protein 1 eta subunit & 39644 & 24996 & 0.63 \\
\hline $\mathrm{C} 15$ & Structure specific recognition protein 1 & 36400 & 23680 & 0.65 \\
\hline C18 & Glutathione peroxidase 1 & 48540 & 24332 & 0.5 \\
\hline $\mathrm{C} 23$ & Amhiphysin & 39140 & 23972 & 0.61 \\
\hline D9 & Cyclin-dependent kinase 4 & 48048 & 25016 & 0.52 \\
\hline D15 & High mobility group box 2 & 42760 & 24760 & 0.58 \\
\hline E10 & Cyclin-dependent kinase inhibitor 1B (P27, Kip1) & 37160 & 23268 & 0.63 \\
\hline E17 & Glutathione-S-transferase mu type 2 (Yb2) & 52532 & 27932 & 0.53 \\
\hline F20 & Diaphorase & 37724 & 23584 & 0.63 \\
\hline H10 & Inhibitor of DNA binding 1 & 56152 & 23828 & 0.42 \\
\hline $\mathrm{J} 10$ & Inhibitor of DNA binding 3 & 56468 & 24028 & 0.43 \\
\hline K10 & Prothymosin $\alpha$ & 36968 & 23168 & 0.63 \\
\hline L11 & Heterogeneous nuclear ribonucleo protein $\mathrm{K}$ & 45492 & 23972 & 0.53 \\
\hline M9 & Cyclin D3 & 36116 & 23460 & 0.65 \\
\hline
\end{tabular}


the cells by antioxidative enzymes and other molecules such as metallothioneins and stress-related proteins.

Gene expression profiles with cadmium exposure at different time points had not yet been investigated in a liver cell line. Hence, we evaluated the pattern of stress gene expression with cadmium exposure after 4,8 or $24 \mathrm{~h}$ on normal rat liver cultured CRL-1439 cells. While cadmium concentration below $100 \mu \mathrm{M}$ would have resulted in a minimum response in various gene expression profiles, concentrations above $100 \mu \mathrm{M}$ would have resulted in the downregulation of many genes due to significant cell population death by severe cadmium toxicity. Therefore, a $100 \mu \mathrm{M}$ cadmium concentration was used for stress gene DNA microarray analysis at different time periods on the cultured liver cells. The nylon membrane used in this study contained a highly focused set of 207 genes coding for various stress proteins and hybridized by radioactive cDNAs. Radioactivelabeled cDNA hybridization is less sensitive than fluorescentlabeled cDNA hybridization. Thus an experimental/control ratio $>1.3$ or $<0.7$ was taken to indicate significant up- or down-regulation of genes (equal to $30 \%$ ). Out of 207 genes analyzed, a maximum of 32 genes $(\sim 15 \%)$ were regulated upon exposure to cadmium. The remaining 175 genes $(\sim 85 \%)$ were not regulated in the control or cadmium-exposed cells. Non-regulation of these genes may indicate that $85 \%$ of genes were not expressed significantly in normal rat liver CRL-1439 cell line. The total number of genes up- and downregulated by $100 \mu \mathrm{M}$ cadmium over $24 \mathrm{~h}$ were nine $(\sim 4 \%)$ and $23(\sim 11 \%)$, respectively, where gene expression profile after each time period showed its own pattern of regulation.

The up-regulation of several stress-related genes after a 4-h exposure with cadmium indicates that the cells were under stress, presumably due to ROS production as reported earlier $(32,33)$. With the increase of exposure time to $8 \mathrm{~h}$, in addition to previous genes up-regulated at $4 \mathrm{~h}$ (Table II), a new set of three genes were up-regulated (Table III). This may further demonstrate an increased stress on cells compared to that at a 4-h exposure to cadmium. At this point, however, cell viability was not compromised, as shown in Fig. 1. After a 24-h exposure, no change in the number of up-regulated genes implies compromization of cell viability due to severe stress conditions which led to cell death.

Interestingly, three genes [hemeoxygenase-1 (HO-1), heat shock HSP 27 protein-1 and heat shock 70-1] were upregulated at $4 \mathrm{~h}$ of treatment and remained so up to $24 \mathrm{~h}$. Since these genes are associated with cellular stress response, the up-regulation of these genes due to cadmium treatment clearly indicates that the cells were under severe stress due to free radical generation. These results are consistent with our earlier studies $(32,33)$, where anti-oxidant enzyme level changes were reported. As it is widely known, heat shock proteins respond to a variety of stress conditions, and act as chaperones. These proteins bind and stabilize proteins which are in the process of folding or assembly in the cells and thereby protect the cells from damage. Earlier it was shown that HO-1 was induced in cells under oxidative stress due to exposure to heavy metals like cadmium (41), by the process of free radical generation. The expression of HO-1 at all incubation periods with cadmium treatment (E7, Tables III-V) in our study, confirms the above observations.
Notably, three genes [glutathione S-transferase mu type 2 (Yb2), inhibitor of DNA binding 3, cyclin D3] were downregulated after $4 \mathrm{~h}$ of treatment and remained so up to $24 \mathrm{~h}$. In a similar way, five genes (glutathione peroxidase 1, high mobility group box 2, heterogeneous nuclear ribonucleoprotein $\mathrm{K}$, cyclin-dependent kinase inhibitor $1 \mathrm{~B}$, inhibitor of DNA binding 1) were down-regulated after $8 \mathrm{~h}$ of treatment and remained so up to $24 \mathrm{~h}$. In our earlier study (32) the glutathione peroxidase (GPx) activity was found decreased after $24 \mathrm{~h}$ of exposure to cadmium at $100 \mu \mathrm{M}$ in normal rat liver cells. In the present study, DNA microarray demonstrated the down-regulation of GPx within $8 \mathrm{~h}$ of treatment with cadmium (C18, Table VI), indicating that gene expression was affected earlier than at the protein level (enzyme activity) due to cadmium exposure.

The genes that were down-regulated were mainly basic cell function genes which help in replication, transcription and translation, cell-cycle regulating genes and other stressresponse genes. The basic cell function genes that were downregulated were genes for inhibitor of DNA binding 1, 2 and 3, glucose regulated protein $58 \mathrm{KD}$, protein disulfide isomerase related protein, high mobility group box 2, nucleoside diphosphate kinase, heterogeneous nuclear ribonucleoprotein $\mathrm{K}$ and proliferating cell nuclear antigen. Recently, it was shown that cadmium treatment reduced the expression of translation initiation factor 4E in a battery of human cell lines (41). This factor was shown to be the cause of toxicity and cell death by cadmium chloride. Another group showed that cadmium treatment decreased the replicative and repair DNA synthesis in $\mathrm{CHO}$ cells (42). Cell-cycle regulating genes that were down-regulated were cyclin D1 and D3, cyclin-dependent kinase 4, and cyclin-dependent kinase inhibitor 1B. Recently it was shown that cadmium down-regulated cyclin-dependent kinases, Cdk-1 and 2 in rat kidney epithelial cells (26). The other stress protein genes that were down-regulated included vimentin, glutathione peroxidase 1 , mitogen activated protein kinase 3, microsomal glutathione S-transferase and glutathione S-transferase mu type 2 (Yb2). Vimentin is primarily concerned with cell elongation and attachment. Its gradual downregulation in this study from the beginning of cadmium treatment indicates that the cells were in the process of detachment due to oxidative stress. This, however, did not affect cell viability up to $8 \mathrm{~h}$ of cadmium exposure (M6, Table VI) due to protection from the high expression level of various heat shock proteins from the beginning, as shown in Tables II and III.

In conclusion, the cells maintained complete viability up to 8 hours with cadmium due to the expression of various heat shock proteins and stress-response proteins like heme oxygenase. With longer exposure periods, due to the downregulation of the basic cell function proteins and cell-cycle regulating proteins, the cells showed toxicity and eventually died. Microarray analysis indicated that cadmium treatment caused a different pattern of gene expression profile at each time period.

\section{Acknowledgements}

This study was supported by National Institutes of Health grant 36-1707-123. 


\section{References}

1. Fay RM and Mumtaz MM: Development of a priority list of chemical mixtures occurring at 1188 hazardous waste sites, using the HazDat database. Food Chem Toxicol 34: 1163-1165, 1996.

2. International Agency for Research on Cancer (IARC): Beryllium, cadmium, mercury and exposure in glass manufacturing Industry. In: Monographs on the Evaluation of the Carcinogenic Risks to Humans. Vol 58, IARC Scientific Publications, Lyon, pp119-237, 1993.

3. Descotes J: Immunotoxicology of cadmium. IARC Sci Publ 118: 385-390, 1992.

4. Dan G, Lall SB and Rao DN: Humoral and cell mediated immune response to cadmium in mice. Drug Chem Toxicol 23: 349-360, 2000

5. Nordberg GF, Kjellström T and Nordberg M: Kinetics and metabolism. In: Cadmium and Health: A Toxicological and Epidemiological Appraisal. Friberg L, Elinder C-G, Kjellström T and Nordberg GF (eds). Vol 1, CRC Press, Boca Raton FL, pp103-178, 1985.

6. Saffron L: Australia cuts cadmium in food. Environ Health Perspect 109: A158, 2001.

7. National Toxicology Program: Report on Carcinogens. 9th edition, US Department of Health and Human Services, Public Health Service, National Toxicology Program, Research Triangle Park, NC, 2000.

8. Waalkes MP: Cadmium carcinogenesis in review. J Inorg Biochem 79: 241-244, 2000.

9. Shalon D, Smith SJ and Brown PO: A DNA microarray system for analyzing complex DNA samples using two-color fluorescent probe hybridization. Genome Res 6: 639-645, 1996.

10. Schena M, Heller RA, Theriault TP, Konrad K, Lachnmeier E and Davis RW: Microarrays: biotechnology's discovery platform for functional genomics. Trends Biotechnol 16: 301-306, 1998.

11. Khan J, Bittner M, Chen Y, Meltzer P and Trent JM: DNA microarray technology: the anticipated impact on the study of human disease. Biochim Biophys Acta 1423: M17-M28, 1999.

12. Debouck $C$ and Goodfellow PN: DNA microarrays in drug discovery and development. Nat Genet 21: 48-50, 1999.

13. Derisi J, Penland L, Brown PO, Bittner ML, Meltzer PS, Ray M, Chen Y, Su YA and Trent JM: Use of a cDNA microarray to analyze gene expression patterns in human cancer. Nat Genet 14: 457-460, 1996.

14. Heller RA, Schena M, Chai A, Shalon D, Bedillion T, Gilmore J, Woolley DE and Davis RW: Discovery and analysis of inflammatory disease-related genes using cDNA microarrays. Proc Natl Acad Sci USA 94: 2150-2155, 1997.

15. Wang DG, Fan JB, Siao CJ, Berno A, Young P, Sapolsky R, Ghandour G, Perkins N, Winchester E and Spenser J: Largescale identification, mapping and genotyping of single-nucleotide polymorphisms in the human genome. Science 280: 1077-1082, 1998.

16. Winzeler EA, Richards DR, Conway AR, Goldstein AL, Kalman S, McCullough MJ, McCusker JH, Stevens DA, Wodicka L and Lockhart DJ: Direct allelic variation scanning of the yeast genome. Science 281: 1194-1197, 1998.

17. Rockett JC and Dix DJ: Application of DNA arrays to toxicology. Environ Health Perspect 107: 681-685, 1999.

18. Nuwaysir EF, Bittner M, Trent J, Barrett JC and Afshari CA: Microarrays and toxicology: the advent of toxicogenomics. Mol Carcinog 24: 153-159, 1999.

19. Medlin J: Timely toxicology. Environ Health Perspect 107: A256-A258, 1999.

20. Herbette S, Taconnat L, Hugouvieux V, Piette L, Magniette ML, Cuine S, Auroy P, Richaud P, Forestier C, Bourguignon J, Renou JP, Vavasseur A and Leonhardt N: Genome-wide transcriptome profiling of the early cadmium response of Arabidopsis roots and shoots. Biochimie 88: 1751-1765, 2006.

21. Sheader DL, Williams TD, Lyons BP and Chipman JK: Oxidative stress response of European flounder (Platichthys flesus) to cadmium determined by a custom cDNA microarray. Mar Environ Res 62: 33-44, 2006.

22. Plessl M, Rigola D, Hassinen V, Aarts MG and Schat H: Transcription profiling of the metal-hyperaccumulator Thlaspi caerulescens. Z Naturforsch 60: 216-223, 2005.
23. Ping H, Brodie LE, Yohey S, McAdams HH and Andersen GL: Whole-genome transcriptional analysis of heavy metal stresses in Caulobacter crescentus. J Bacteriology 187: 8437-8449, 2005.

24. Regunathan A, Glesne DA, Wilson AK, Song J, Nicolae D, Flores T and Bhattacharyya MH: Microarray analysis of changes in bone cell gene expression early after cadmium gavage in mice. Toxicol Appl Pharmacol 191: 272-293, 2003.

25. Zhou T, Jia X, Chapin RE, Maronpot RR, Harris MW, Liu J, Waalkes MP and Eddy EM: Cadmium at a non-toxic dose alters gene expression in mouse testes. Toxicol Lett 154: 191-200, 2004.

26. Xie J and Shaikh ZA: Cadmium induces cell cycle arrest in rat kidney epithelial cells in G2/M phases. Toxicology 224: 56-65, 2006.

27. Bernhard D, Rossmann A, Henderson B, Kind M, Seubert A and Wick G: Increased serum cadmium and strontium levels in young smokers: effects on arterial endothelial cell gene transcription. Arterioscler Thromb Vase Biol 26: 833-838, 2006.

28. Tsangaris G, Botsonis A, Politis I and Tzortzatou-Stathopoulou F: Evaluation of cadmium-induced transcriptome alterations by three color cDNA labeling microarray analysis on a T-cell line. Toxicology 178: 135-160, 2002.

29. Koizumi S and Yamada H: DNA Microarray analysis of altered gene expression in cadmium-exposed human cells. J Occu Health 45: 331-334, 2003.

30. Bae DS, Hanneman WH, Yang RS and Campain JA: Characterization of gene expression changes associated with MNNG, arsenic, or metal mixture treatment in human keratinocytes: application of cDNA microaaay technology. Environ Health Perspect 110: 931-941, 2002.

31. Koizumi S and Yamada H: DNA microarray analysis of human gene expression induced by a non-lethal dose of cadmium. Ind Health 40: 159-166, 2002.

32. Ikediobi CO, Badisa VL, Lambert TAT, Latinwo LM and West J: Response of antioxidant enzymes and redox metabolites to cadmium-induced oxidative stress in CRL-1439 normal rat liver cells. Int J Mol Med 14: 87-92, 2004.

33. Latinwo LM, Badisa VL, Ikediobi CO, Odewumi CO, Lambert TAT and Badisa RB: Effect of cadmium-induced oxidative stress on antioxidative enzymes in mitochondria and cytoplasm of CRL1439 rat liver cells. Int J Mol Med 18: 477-481, 2006.

34. Badisa RB, Tzakou O, Couladis M and Pilarinou E: Cytotoxic activities of some Greek Labiatae herbs. Phytother Res 17: 472-476, 2003.

35. Ipsen J and Feigl P: Bancroft's Introduction to Biostatistics. 2nd edition, Harper and Row, New York, p164, 1970.

36. Hinkle PM, Kinsella PA and Osterhoudt KC: Cadmium uptake and toxicity via voltage sensitive calcium channels. J Biol Chem 262: 16333-16337, 1987.

37. Coutant A, Lebeau J, Bideon-Wagner N, Levalois C, Lectard B and Chevillard S: Cadmium-induced apoptosis in lymphoblastoid cell line: involvement of caspase-dependent and -independent pathways. Biochimie 88: 1815-1822, 2006.

38. Badisa RB, Ayuk-Takem TL, Ikediobi CO and Walker EHL: Selective anticancer activity of pure licamichauxiioic-B acid in cultured cell lines. Pharm Biol 44: 141-145, 2006.

39. Urani C, Melchioretto P, Canevali C and Crosta GF: Cytotoxicity and induction of protective mechanisms in HepG2 cells exposed to cadmium. Toxicol in vitro 19: 887-892, 2005.

40. Fan W, Agarwal N, Kumar MD and Cooper NG: Retinal ganglion cell death and neuroprotection: Involvement of the CaMKII alpha gene. Brain Res Mol Brain Res 139: 306-316, 2005.

41. Othumpangat S, Kashon M and Joseph P: Eukarotic translation initiation factor $4 \mathrm{E}$ is a cellular target for toxicity and death due to exposure to cadmium chloride. J Biol Chem 280: 25162-25169, 2005.

42. Banfalvi G, Littlefield N, Hass B, Mikhailova M, Csuka I, Szepessy E and Chou MW: Effect of cadmium on the relationship between replicative and repair DNA synthesis in synchronized CHO cells. Eur J Biochem 267: 6580-6585, 2000. 